\title{
АНАЛІЗ ОСВІТНЬО-ПРОФЕСІЙНИХ ПРОГРАМ ПЕРШОГО РІВНЯ ВИЩОЇ ОСВІТИ СПЕЦІАЛЬНОСТІ «ФАРМАЦІЯ, ПРОМИСЛОВА ФАРМАЦІЯ»
}

\section{Крвавич А. С., Губицька I. I.}

\section{ВСТУП}

Фармацевтична галузь України в останні роки має динамічні темпи зростання та активного розвитку. Об'єм українського фармацевтичного ринку становить понад 35 млрд грн і впродовж останніх років має сталу тенденцію до зростання. Вітчизняна фармацевтична індустрія впевнено займає впливові позиції на фармацевтичному ринку по реалізації своєї продукції. Основними завданнями на сучасному етапі підготовки кадрів для фармацевтичної галузі $\epsilon$ інновація та інформатизація, які забезпечують гуманізацію та індивідуалізацію освітнього процесу, враховують тенденції формування загальноєвропейського освітнього простору та особивості вітчизняної системи професійної освіти.

Фармацевтична освіта - складна і гетерогенна соціальна система цілеспрямованої підготовки та вдосконалення практичних i науково-педагогічних фармацевтичних кадрів.

Відповідно до принципів світової системи освіти XXI ст. в основі моделі сучасної фармацевтичної освіти повинні бути закладені етика професії, цілісність особистості та світосприйняття, фармацевтична культура і свідомість. Ї̈̈ пріоритетами є:

- забезпечення єдності фармацевтичного простору в умовах розмаїття видів фармацевтичних організацій та регіональних моделей фармацевтичного ринку;

- формування у фахівців позитивної мотивації до освіти через все життя завдяки усвідомленню пропонованих вимог до рівня професійної підготовки і критеріїв ії оцінки;

- перехід до диференційованої оцінки результатів праці фахівців на основі відповідності виконуваних функцій установленим нормам;

- приймання обгрунтованих управлінських рішень; 
- гарантування фахівцям виконання своїх функціональних обов'язків відповідно до їхніх здібностей та інтересів ${ }^{1}$.

Національний університет «Львівська політехніка» найстаріший вищий технічний навчальний заклад України та Східної Свропи, державний заклад вищої освіти IV рівня акредитації. Його випускники працюють в усіх галузях народного господарства нашої держави та в багатьох країнах світу, чимало 3 них обіймають найвищі посади у владних, бізнесових та фінансових структурах, науці та індустрії України. За результатами рейтингу, який проводиться щорічно на підставі оцінок експертів, НУ «Львівська політехніка» вже протягом багатьох років належить до десятки найкращих вищих навчальних закладів України.

Студенти НУ «Львівська політехніка» навчаються в країнах Європейського Союзу за різними навчальними програмами. За останні 5 років 16 студентів Інституту хімії та хімічної технології навчались в європейських університетах, у тому числі 4 рази за програмою «Erasmus +». Така освітня мобільність потребує постійного моніторингу та вдосконалення освітніх програм підготовки спеціалістів, зокрема першого (бакалаврського) рівня.

У зв'язку з цим одним із завдань, задекларованих у Стратегічному плані розвитку Львівської політехніки до 2025 року, є удосконалення процесів викладання та навчання, що передбачає оптимізацію змісту освітніх програм та зменшення кількості їхніх компонентів.

3 цією метою в Національному університеті «Львівська політехніка» впродовж 2020 року були здійснені та плануються такі заходи:

- впроваджено ігрові та імітаційні форми навчання;

- збільшення частки здобувачів вищої освіти (громадян України), які захистили кваліфікаційну роботу іноземною мовою (мовою країн-учасників ОЕСР);

- запровадження різних форм контекстного та проблемного навчання;

- розроблення освітніх програм та ліцензування спеціальностей для підготовки іноземних громадян;

${ }^{1}$ Громовик Б.П., Горілик А.В. Неперервна фармацевтична освіта в Україні: науково-методичні аспекти управлінсько-економічної підготовки : монографія. Львів: Растр-7, 2012. 166 с. С. 51. 
- запровадження перепідготовки фахівців за заочно-дистанційною формою навчання;

- збільшення щорічної кількості програм академічної нобільності студентів та аспірантів;

- організація додаткових занять із фундаментальної підготовки;

- збільшення частки освітньо-професійних програм, зміст яких погоджений з працедавцями;

- збільшення кількості іноземних фахівців, які відвідали НУ «Львівська політехніка» за програмами «visitingprofessor», працевлаштовані в університет або які прочитали лекції;

- міжнародна акредитація освітніх програм;

- забезпечення частки викладання окремих навчальних компонентів англійською мовою;

- збільшення кількості спеціальностей, підготовка за якими реалізується відповідно до засад «дуальної освіти»;

- укладання договорів з підприємствами (фірмами, компаніями) щодо цільової підготовки фахівців.

НУ «Львівська політехніка» - це 16 навчально-наукових інститутів, а також Інститут післядипломної освіти, Міжнародний інститут освіти, культури та зв'язків 3 діаспорою. До складу Інституту хімії та хімічних технологій входить 9 кафедр, серед яких - кафедра технології біологічно активних сполук, фармації та біотехнології, яка $є$ випусковою за спеціальністю 226 «Фармація, промислова фармація». Підготовка бакалаврів 3 фармації, промислової фармації здійснюється за освітньо-професійною програмою, яка базується на загальновідомих положеннях та результатах сучасних наукових досліджень $з$ фармації та промислової фармації для виробництва фармацевтичних препаратів (у т.ч. ветеринарних i біомедпрепаратів), оцінки якості лікарських засобів, моделювання i проектування фармацевтичних підприємств у системі GMP, економіки фармацевтичних підприємств та орієнтує на актуальні спеціалізації, в рамках яких можлива подальша професійна та наукова кар'єра. Основний фокус освітньої програми - це промислова фармація, а підготовка бакалаврів здійснюється для організаційно-управлінської, інвестиційної та науково-дослідної діяльності у сфері фармації та промислової фармації, для створення науково-технічного потенціалу для синтезу нових та відомих лікарських субстанцій, виготовлення готових лікарських препаратів та контролю їхньої якості, розподілу, регулювання забезпечення 
лікарськими засобами, а також консультування, надання інформації щодо лікарських засобів.

Як показує аналіз досвіду освітніх систем багатьох країн, одним зі шляхів оновлення змісту освіти й навчальних технологій відповідно до сучасних потреб, інтеграції до освітнього простору $є$ орієнтація навчальних програм на компетентнісний підхід i створення механізму його запровадження.

Поняття компетентностей та компетенцій науково обгрунтовано вченими країн Європейського союзу в середині $80-x$ років минулого століття. Європейські експерименти розглядають поняття компетентності як загальні, ключові або базові вміння, ключові кваліфікації. Ними визначено також поняття «компетентність» як здатність успішно задовольняти індивідуальні й соціальні потреби, діяти й виконувати поставлені завдання² .

В основі концепції компетентності лежить ідея виховання компетентної людини й працівника, який не лише має необхідні знання, професіоналізм, але й уміє діяти адекватно у відповідних ситуаціях, застосовуючи ці знання, й бере на себе відповідальність за певну діяльність.

Відомі міжнародні організації, що нині працюють у сфері освіти, останнім часом вивчають проблеми, що пов'язані 3 появою компетентнісно орієнтованої освіти, серед яких ЮНЕСКО, ЮНІСЕФ, ПРООН, Рада Європи, Міжнародний департамент стандартів. Компетентнісно орієнтований підхід до формування змісту освіти став новим концептуальним орієнтиром у світі. У багатьох Європейських країнах сьогодні результати навчання базуються на досягненні учнями необхідних компетентностей ${ }^{3}$.

Сучасні тенденції розвитку роблять системоутворюючий вплив на реформування системи вищої освіти України й передбачають:

- перехід до динамічної ступеневої системи підготовки фахівців, що дають змогу задовольняти можливості особистості в здобутті певного освітнього й кваліфікаційного рівня відповідно до іiі здібностей, забезпечити ії мобільність на ринку праці;

${ }^{2}$ Mertens D., Hopson R. Advancing evaluation of STEM efforts through attention to diversity and culture. Critical Issues in STEM Evaluation. 2006. № 109. P. 42. https://doi.org/10.1002/ev.177.

${ }^{3}$ Тараненко І. Розвиток життєвої компетентності та соціальної інтеграції: досвід Європейських країн Кроки до компетентності та інтеграції в суспільстві / за ред. І.Г. Єрмакова. Київ : «Контекст», 2000. С. 129. 
- підвищення освітнього й культурного рівнів суспільства: створення умов для навчання протягом усього життя;

- наближення вищої освіти України до рівня вищої освіти в розвинутих країнах світу та іiі інтеграція в міжнародне науковоосвітне співтовариство ${ }^{4}$.

У розвинутих країнах світу інформатизацію освіти вважають вирішальним напрямом іiї модернізації, позаяк вона полегшує доступ до освіти, підвищує якість освітніх послуг. Важливе значення в самоосвіті має дистанційне навчання - вид навчання, заснований на комплексному використанні освіти шляхом листування i використання технічних засобів передачі інформації. Особливості дистанційного навчання: можливість просторового i часового розділення викладача і слухача; спеціалізоване інформаційно-освітне середовище; застосування інформаційно-комунікаційних технологій (зокрема, віртуальних навчальних середовищ - ВНС), заснованих на використанні персональних комп'ютерів, відео- й аудіотехніки, мультимедійних засобів навчання.

Незважаючи на досягнення вищої освіти України, в системі навчання у закладах вищої освіти (далі - ЗВО) для підготовки фармацевтичних кадрів необхідні зміни, що пов'язано із:

- встановленням ринкових відносин на фармацевтичному ринку;

- обміном досвідом на світовому та європейському рівнях у фармацевтичній галузі;

- необхідністю появи на ринку праці нових спеціальностей, посад;

- постійним наповненням та вдосконаленням змісту освіти тощо 5

\section{1. Аналіз освітньо-професійних програм (ОПП)}

першого (бакалаврського) рівня вищої освіти спеціальності 226 «Фармація, промислова фармація» НУ «Львівська політехніка»

\section{з українськими 3ВО}

Бакалавр - це освітній ступінь, що присуджується закладом вищої освіти в результаті успішного виконання здобувачем вищої освіти освітньо-професійної програми, обсяг якої становить 240 кредитів

${ }^{4}$ Кубенко І.М. Що таке компетентність і як їі розуміють в освіті. Додаток до електронного журналу «Теорія та методика управління освітою». 2010. Вип № 1. С. 12.

5 3’їзди фармації України - історія розвитку галузі / В.П. Черних, А.А. Котвіцька, В.А. Георгіянц та ін. Вісник фармації. 2012. № 1(69). С. 3-5. 
ЄКТС на основі повної загальної середньої освіти. У багатьох європейських країнах бакалаврат традиційно вважається першим ступенем загальної системи вищої освіти. Протягом навчання студент набуває базових практичних i теоретичних знань, які потрібні для роботи за професією ${ }^{6}$.

Для порівняльної характеристики освітньої програми нами було проаналізовано обсяг навчального навантаження здобувача вищої освіти відповідно до циклів підготовки трьох закладів вищої освіти, а саме: Національного університету «Львівська політехніка», Приватного вищого навчального закладу «Київський міжнародний університет» ${ }^{7}$, Одеського політехнічного університету $^{8}$ та Київського Національного університету технологій та дизайну (далі - КНУТД) ${ }^{9}$. Результати представлені в табл. 1-4.

У результаті навчання в Одеському національному політехнічному університеті студенти будуть набувати компетентності й розвивати вміння та навички, які підготують їх до виконання інженерних завдань зі стандартизації, проектування та забезпечення виробництва хіміко-фармацевтичної продукції. Освітня програма фокусуєтся на дослідженні технології одержання лікарських речовин, лікарських препаратів та парфумерно-косметичних засобів.

Особливості програми підготовки бакалавра в Київському міжнародному університеті полягає у формуванні здатності застосовувати набуті знання, навички, вміння i розуміння з гуманітарних, фундаментальних та професійно-орієнтованих дисциплін для вирішення типових задач на відповідній посаді у фармацевтичної діяльності, яка включає обіг лікарських засобів і товарів аптечного асортименту, їх зберігання, контроль якості, гарантування безпечного та раціонального застосування лікарських засобів, надання фармацевтичної опіки на засадах фармацевтичної етики й деонтології.

${ }^{6}$ Захарченко В.М. Розроблення освітніх програм. Методичні рекомендації / В.М. Захарченко та ін. ; за ред. В Г. Кременя. Київ : Пріоритети, 2014. 120 с.

${ }^{7}$ Освітньо-професійна програма Київського міжнародного університету. URL: https://kymu.edu.ua/osvitnya-programa-farmatsiya/

${ }^{8}$ Освітньо-професійна програма Одеського національного політехнічного університету. URL: https://opu.ua/education/programs/bac-226-1

9 Освітньо-професійна програма Київського національного університету технологій та дизайну. URL: https://knutd.edu.ua/ekts/opfchbt/opfchbt-bhf/disc-bchf/ 
Таблиця 1

\begin{tabular}{|c|c|c|c|c|}
\hline \multirow[b]{2}{*}{$\begin{array}{l}\text { № } \\
\text { пI/II }\end{array}$} & \multirow[b]{2}{*}{$\begin{array}{c}\text { Цикл } \\
\text { підготовки }\end{array}$} & \multicolumn{3}{|c|}{$\begin{array}{c}\text { Обсяг навчального навантаження здобувача } \\
\text { вищої освіти (кредитів/\%) НУ ЛП }\end{array}$} \\
\hline & & $\begin{array}{c}\text { Обов'язкові } \\
\text { компоненти } \\
\text { освітньо- } \\
\text { професійної } \\
\text { програми }\end{array}$ & $\begin{array}{c}\text { Вибіркові } \\
\text { компоненти } \\
\text { освітньо- } \\
\text { професійної } \\
\text { програми }\end{array}$ & $\begin{array}{c}\text { Всього за весь } \\
\text { термін } \\
\text { навчання }\end{array}$ \\
\hline 1. & $\begin{array}{l}\text { Цикл загальної } \\
\text { підготовки }\end{array}$ & $91 / 38$ & $6 / 2,5$ & $97 / 40,5$ \\
\hline 2. & $\begin{array}{l}\text { Цикл } \\
\text { професійної } \\
\text { підготовки }\end{array}$ & $88,5 / 37$ & $54,5 / 22,5$ & $143 / 59,5$ \\
\hline $\begin{array}{l}\text { Всьо } \\
\text { терм }\end{array}$ & $\begin{array}{l}\text { го за весь } \\
\text { ін навчання }\end{array}$ & $179,5 / 75$ & $60,5 / 25$ & $240 / 100$ \\
\hline
\end{tabular}

Таблиця 2

\begin{tabular}{|c|l|c|c|c|}
\hline \multirow{2}{*}{$\begin{array}{c}\text { № } \\
\text { п/п }\end{array}$} & \multicolumn{1}{|c|}{$\begin{array}{c}\text { Цикл } \\
\text { підготовки }\end{array}$} & $\begin{array}{c}\text { Обог навчального навантаження здобувача } \\
\text { вищої освіти (кредитів /\%) КМУ } \\
\text { компоненти } \\
\text { освітньо- } \\
\text { професійної } \\
\text { програми }\end{array}$ & $\begin{array}{c}\text { Вибіркові } \\
\text { компоненти } \\
\text { освітньо- } \\
\text { професійної } \\
\text { програми }\end{array}$ & $\begin{array}{c}\text { Всього } \\
\text { за весь термін } \\
\text { навчання }\end{array}$ \\
\hline 1. & $\begin{array}{l}\text { Цикл загальної } \\
\text { підготовки }\end{array}$ & $72 / 30$ & $21 / 8,75$ & $93 / 38,75$ \\
\hline \multirow{2}{2}{2.} & $\begin{array}{l}\text { Цикл } \\
\text { професійної } \\
\text { підготовки }\end{array}$ & $108 / 45$ & $39 / 16,25$ & $147 / 61,25$ \\
\hline $\begin{array}{l}\text { Всього за весь } \\
\text { термін навчання }\end{array}$ & $180 / 75$ & $60 / 25$ & $240 / \mathbf{1 0 0}$ \\
\hline
\end{tabular}


Таблиця 3

\begin{tabular}{|c|c|c|c|c|}
\hline \multirow[b]{2}{*}{$\begin{array}{l}\text { № } \\
\text { ПI/ா }\end{array}$} & \multirow[b]{2}{*}{$\begin{array}{c}\text { Цикл } \\
\text { підготовки }\end{array}$} & \multicolumn{3}{|c|}{$\begin{array}{c}\text { Обсяг навчального навантаження здобувача } \\
\text { вищої освіти (кредитів /\%) Одеський НПУ }\end{array}$} \\
\hline & & $\begin{array}{l}\text { Обов'язкові } \\
\text { компоненти } \\
\text { освітньо- } \\
\text { професійної } \\
\text { програми }\end{array}$ & $\begin{array}{c}\text { Вибіркові } \\
\text { компоненти } \\
\text { освітньо- } \\
\text { професійної } \\
\text { програми }\end{array}$ & $\begin{array}{c}\text { Всього } \\
\text { за весь термін } \\
\text { навчання }\end{array}$ \\
\hline 1. & $\begin{array}{l}\text { Цикл загальної } \\
\text { підготовки }\end{array}$ & $53 / 22$ & $29 / 12$ & $82 / 34$ \\
\hline 2. & \begin{tabular}{|l|} 
Цикл \\
професійної \\
підготовки
\end{tabular} & $91,5 / 38$ & $54,5 / 23$ & $146 / 61$ \\
\hline \multicolumn{2}{|c|}{$\begin{array}{l}\text { Всього за весь термін } \\
\text { навчання }\end{array}$} & $144,5 / 60$ & $95,5 / 40$ & $240 / \mathbf{1 0 0}$ \\
\hline
\end{tabular}

Таблиця 4

\begin{tabular}{|c|l|c|c|c|}
\hline \multirow{2}{*}{$\begin{array}{c}\text { № } \\
\text { п/п }\end{array}$} & \multicolumn{1}{|c|}{$\begin{array}{c}\text { Обсяг } \\
\text { підготовки }\end{array}$} & $\begin{array}{c}\text { Обовчального навантаження здобувача } \\
\text { компоненти } \\
\text { освітнь- } \\
\text { професійної } \\
\text { програми }\end{array}$ & $\begin{array}{c}\text { Вибіркові } \\
\text { компоненти } \\
\text { освітньо- } \\
\text { професійної } \\
\text { програми }\end{array}$ & $\begin{array}{c}\text { Всього } \\
\text { за весь термін } \\
\text { навчання }\end{array}$ \\
\hline 1. & $\begin{array}{l}\text { Цикл загальної } \\
\text { підготовки }\end{array}$ & $99 / 41,25$ & $18 / 7,5$ & $82 / 48,75$ \\
\hline 2. & $\begin{array}{l}\text { Цикл } \\
\text { професійної } \\
\text { підготовки }\end{array}$ & $81 / 33,75$ & $42 / 17,5$ & $146 / 51,25$ \\
\hline $\begin{array}{l}\text { Всього за весь термін } \\
\text { навчання }\end{array}$ & $180 / 75$ & $60 / 25$ & $240 / 100$ \\
\hline
\end{tabular}

Програма підготовки бакалавра в КНУТД орієнтована на формування у здобувачів компетентностей щодо набуття глибоких знань, умінь та навичок зі спеціальності. Обов'язкові навчальні модулі - 75\%, 3 них: дисципліни загальної підготовки - 42\%, професійної підготовки - 32\%, практична підготовка - 13\%, вивчення іноземної мови - 13\%. Дисципліни вільного вибору студента - 25\%, із них, що розширюють загальні компетентності, $30 \%$, професійні $-70 \%$. 


\begin{tabular}{|c|c|c|c|c|c|c|c|c|c|}
\hline 톨 & 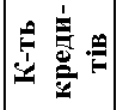 & $\begin{array}{c}0 \\
\mathbb{N}\end{array}$ & $\begin{array}{l}0 \\
\text { I }\end{array}$ & $\overbrace{0}^{\circ}$ & $\overbrace{0}^{\circ}$ & $\overbrace{0}^{\circ}$ & $\overbrace{0}^{\circ}$ & $\overbrace{0}^{\circ}$ & $\begin{array}{l}\text { O } \\
\text { n. }\end{array}$ \\
\hline 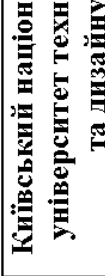 & 产 & 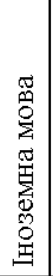 & 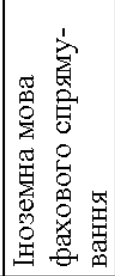 & 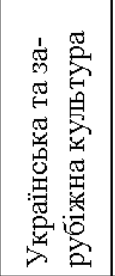 & 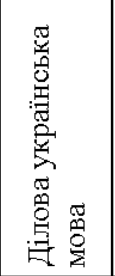 & 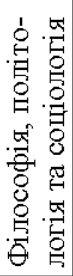 & 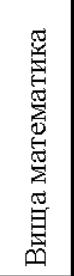 & 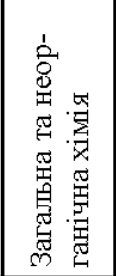 & 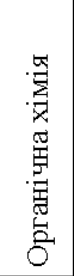 \\
\hline \multirow{2}{*}{ 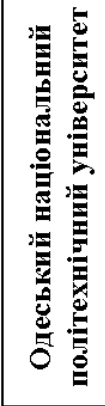 } & 点 & & $\stackrel{\circ}{6}$ & $\stackrel{\circ}{m}$ & $\stackrel{\circ}{m}$ & $\stackrel{\circ}{m}$ & $\stackrel{\circ}{\circ}$ & $\stackrel{n}{\approx}$ & $n$ \\
\hline & 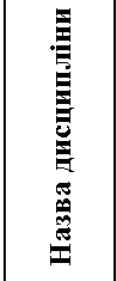 & & 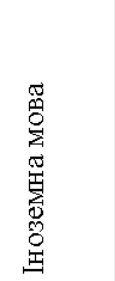 & 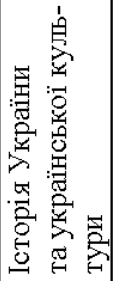 & 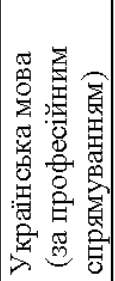 & 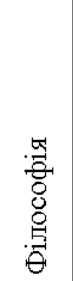 & 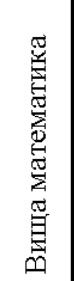 & 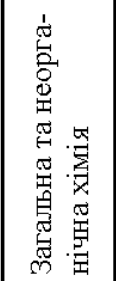 & 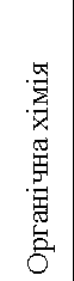 \\
\hline \multirow{2}{*}{ 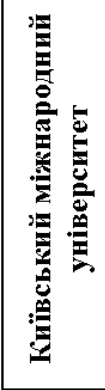 } & 息 & & m. & $\stackrel{\circ}{\rho_{1}}$ & $\begin{array}{l}0 \\
m\end{array}$ & m & $\begin{array}{l}0 \\
m\end{array}$ & $m$ & $0_{n}^{0}$ \\
\hline & 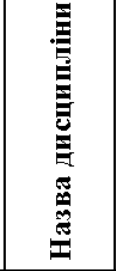 & & 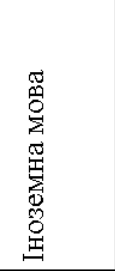 & 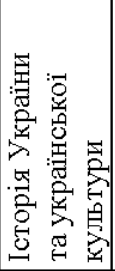 & 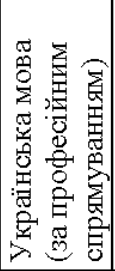 & 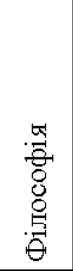 & 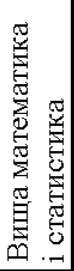 & 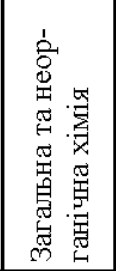 & 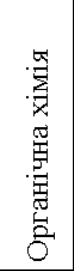 \\
\hline \multirow{2}{*}{ 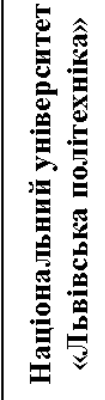 } & 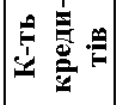 & & $\begin{array}{l}\text { ○. } \\
\text { ñ }\end{array}$ & m. & $\begin{array}{l}\rho_{n} \\
\text { man }\end{array}$ & $\stackrel{\circ}{m}$ & $\stackrel{0}{\sim}$ & $\begin{array}{l}0 \\
\text { in }\end{array}$ & $\begin{array}{l}\text { on } \\
\text { n' }\end{array}$ \\
\hline & 吾 & 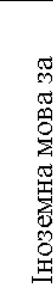 & 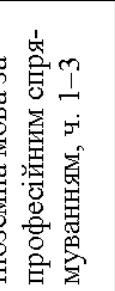 & 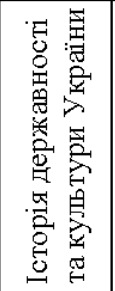 & 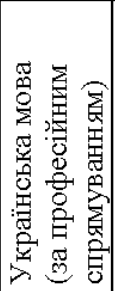 & $\begin{array}{l}.5 \\
\frac{5}{8} \\
8 \\
0 \\
.9 \\
\theta \\
\theta\end{array}$ & 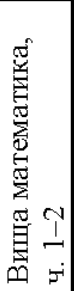 & 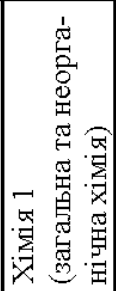 & 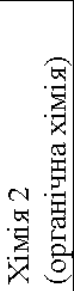 \\
\hline
\end{tabular}


n

\begin{tabular}{|c|c|c|c|c|c|c|c|c|c|}
\hline ' & $\underset{6}{0}$ & ' & ' & $\stackrel{0}{6}$ & $\stackrel{0}{a}$ & ' & I & $\begin{array}{l}0 \\
0 \\
n\end{array}$ & $\stackrel{0}{6}$ \\
\hline 1 & $\begin{array}{l}\text { 总 } \\
\text { 兽 }\end{array}$ & 1 & 1 & 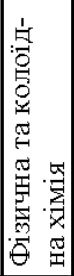 & 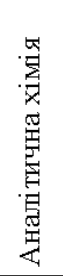 & 1 & 1 & 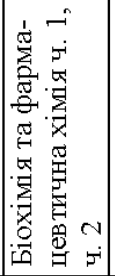 & 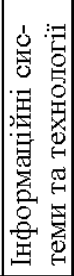 \\
\hline$\stackrel{\circ}{m}$ & $\stackrel{0}{\circ}$ & $n$ & $\stackrel{\circ}{\infty}$ & $\stackrel{\circ}{\circ}$ & $\stackrel{\circ}{m}$ & $\begin{array}{l}0 \\
\text { in }\end{array}$ & ' & $\stackrel{0}{n}$ & $\stackrel{0}{n}$ \\
\hline 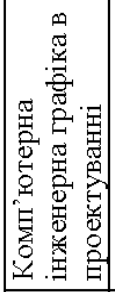 & 莺 & 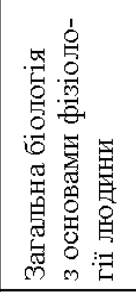 & 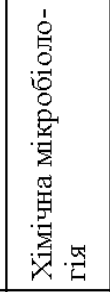 & 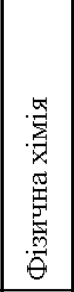 & 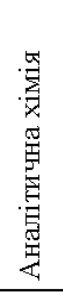 & 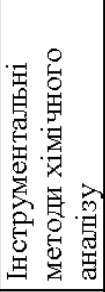 & 1 & 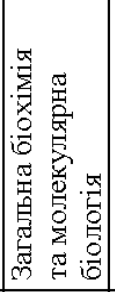 & 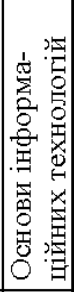 \\
\hline$\stackrel{\circ}{m}$ & $\stackrel{0}{m}$ & $\stackrel{0}{\circ} \quad n$ & $\begin{array}{l}0 \\
n\end{array}$ & $\stackrel{0}{f}$ & $\stackrel{0}{\infty}$ & $\stackrel{0}{n}^{\prime}$ & ' & $\begin{array}{l}0 \\
\text { in }\end{array}$ & $\stackrel{0}{m}$ \\
\hline 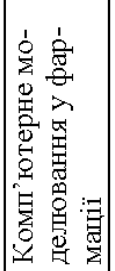 & 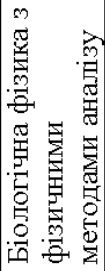 & 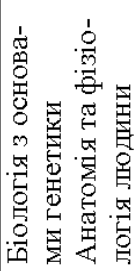 & 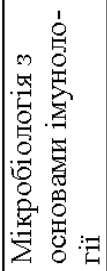 & 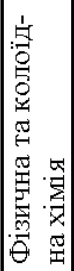 & 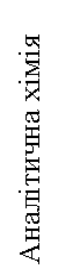 & 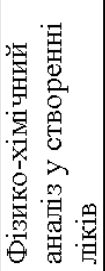 & 1 & 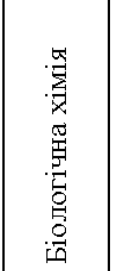 & 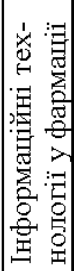 \\
\hline$\stackrel{0}{\forall}$ & $0_{n}$ & $o_{n}$ & $0_{n}$ & $0_{n}$ & $\stackrel{0}{f}$ & $\stackrel{\circ}{\forall}$ & $\stackrel{\circ}{\forall}$ & $\stackrel{0}{\infty}$ & $\stackrel{0}{m}$ \\
\hline 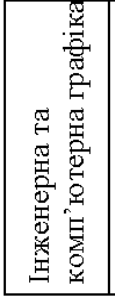 & 总 & 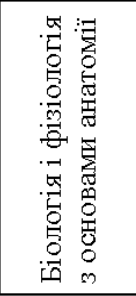 & 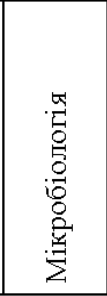 & 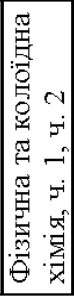 & 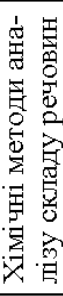 & 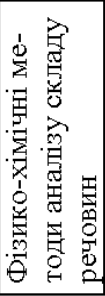 & 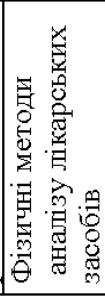 & 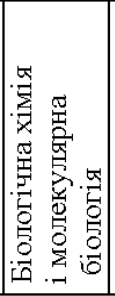 & 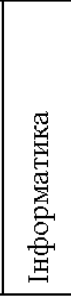 \\
\hline
\end{tabular}




\begin{tabular}{|c|c|c|c|c|c|c|c|c|}
\hline I & 1 & ஜ & 1 & ' & 1 & I & $\stackrel{0}{0}$ & $\stackrel{\circ}{0}$ \\
\hline 1 & 1 & 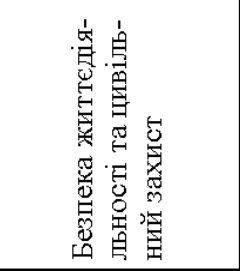 & 1 & 1 & 1 & 1 & 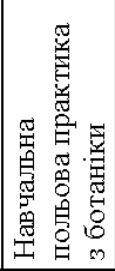 & 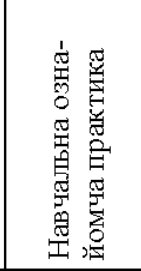 \\
\hline m & $\stackrel{\circ}{\circ}$ & m & ' & ' & $=$ & $n$ & ' & $\mathfrak{n}^{n}$ \\
\hline 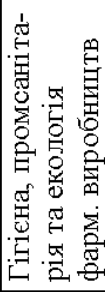 & 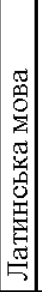 & 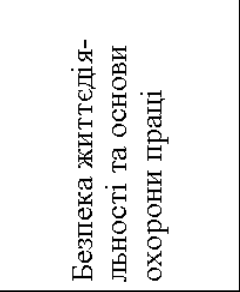 & 1 & 1 & 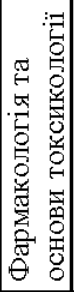 & 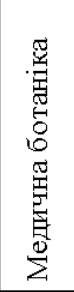 & I & 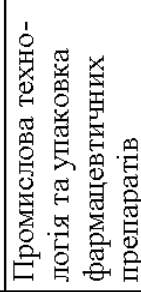 \\
\hline $\begin{array}{cc}0 & 0 \\
m & m\end{array}$ & @) & $\begin{array}{cc}0 & 0 \\
m & m\end{array}$ & m & $\begin{array}{ll}0 & 0 \\
m & m\end{array}$ & $\infty$ & $0_{n}$ & m. & $\begin{array}{ll}0 & 0 \\
0 & \stackrel{f}{f}\end{array}$ \\
\hline 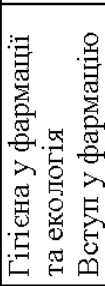 & 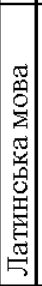 & 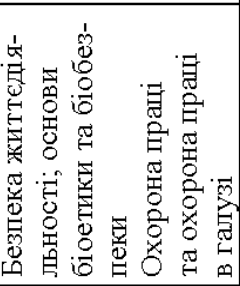 & 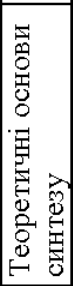 & 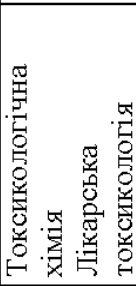 & 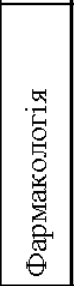 & 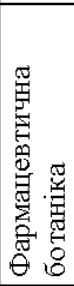 & 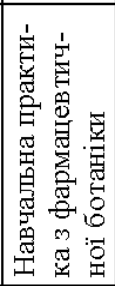 & 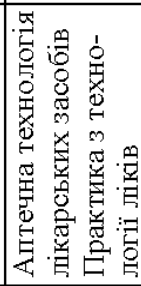 \\
\hline$\stackrel{\circ}{\forall}$ & ली & m & $\vartheta_{0}$ & $\stackrel{0}{\forall}$ & $\stackrel{\circ}{\forall}$ & $\vartheta_{0}$ & m & $\stackrel{n}{\infty} \stackrel{n}{\sim}$ \\
\hline 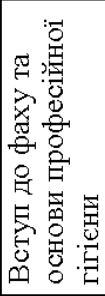 & 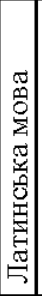 & 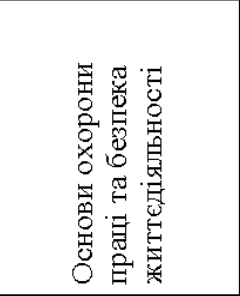 & 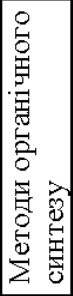 & 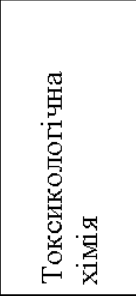 & 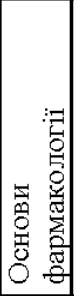 & 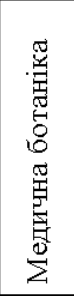 & 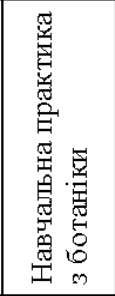 & 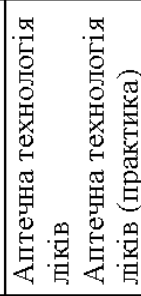 \\
\hline
\end{tabular}




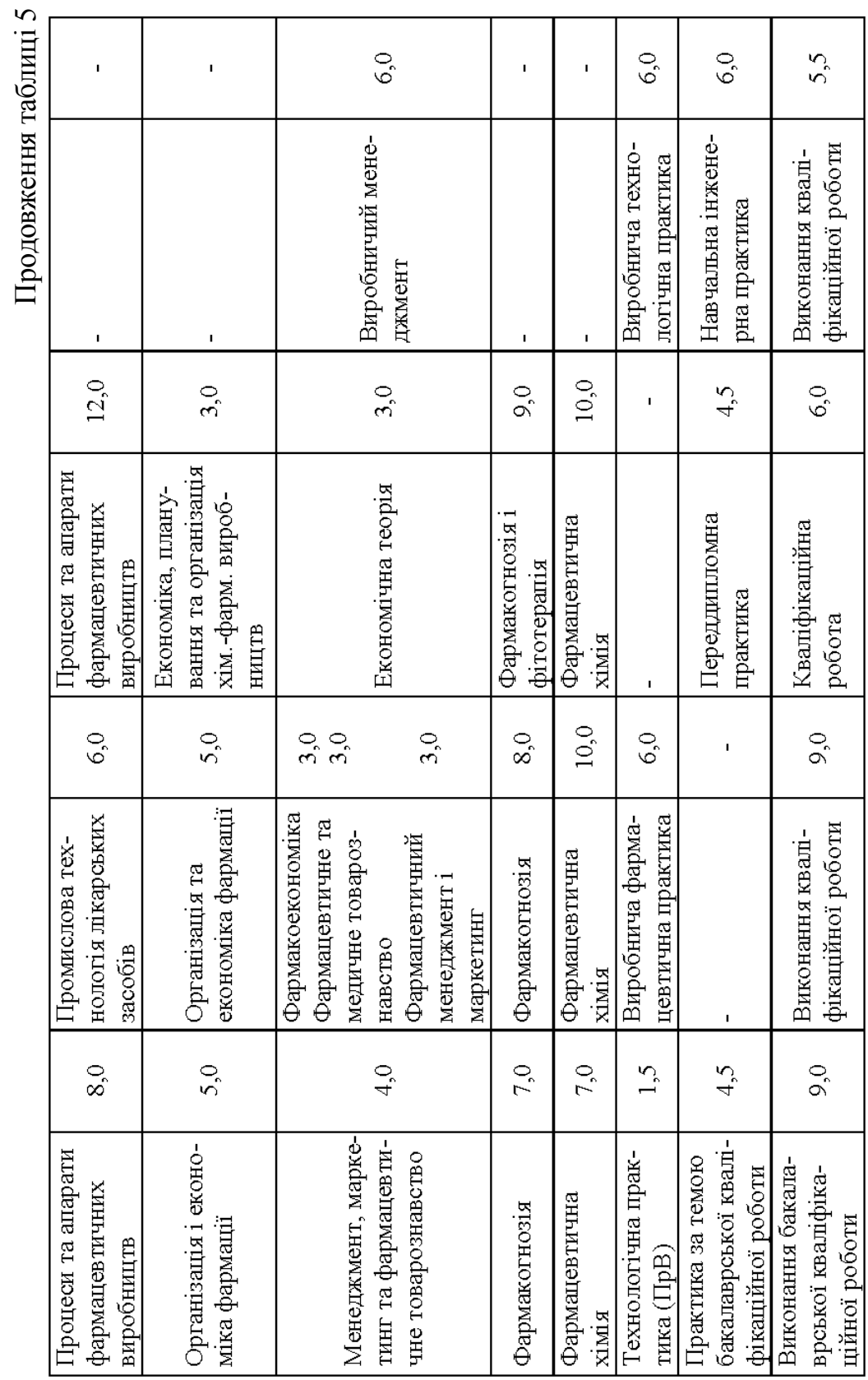




\begin{tabular}{|c|c|c|c|c|c|c|c|c|}
\hline$\overbrace{}^{\circ}$ & 1 & ' & $\frac{\circ}{i}$ & ' & 1 & 1 & 1 & ' \\
\hline 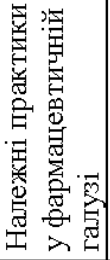 & 1 & 1 & 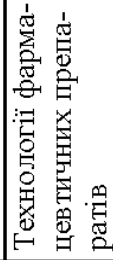 & 1 & 1 & 1 & I & 1 \\
\hline$\stackrel{n}{*}$ & ' & ' & $n^{n}$ & ' & ' & $\infty$ & $\stackrel{n}{*}$ & $\stackrel{\circ}{m}$ \\
\hline 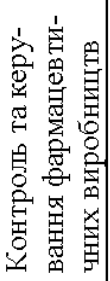 & 1 & I & 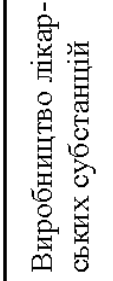 & I & & 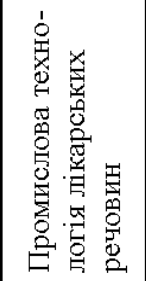 & 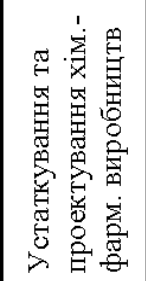 & 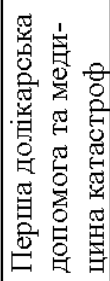 \\
\hline$\stackrel{0}{m}$ & $\stackrel{\circ}{\forall}$ & $\stackrel{0}{m}$ & $\mathrm{o}_{n}$ & $\overbrace{0}$ & & $\stackrel{\circ}{\forall}$ & $\stackrel{0}{m}$ & $\stackrel{0}{m}$ \\
\hline 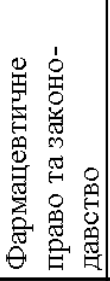 & 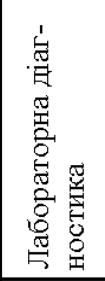 & 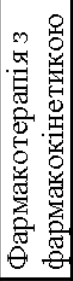 & 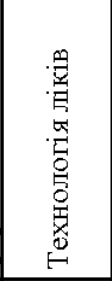 & 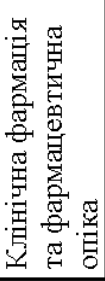 & & $\begin{array}{l}r \\
\\
\end{array}$ & 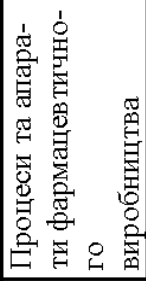 & 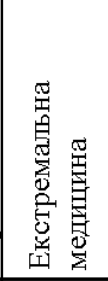 \\
\hline$\stackrel{0}{m}$ & $\stackrel{\circ}{m}$ & $\stackrel{\circ}{m}$ & $0_{n}$ & $\stackrel{\circ}{\forall}$ & $\stackrel{0}{\circ}$ & $\stackrel{0}{n}$ & $\stackrel{0}{\infty}$ & $m$ \\
\hline 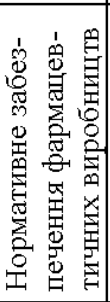 & 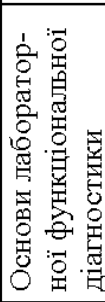 & 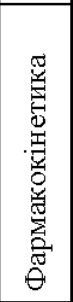 & 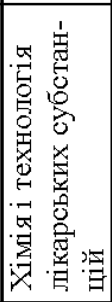 & 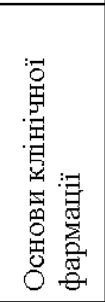 & 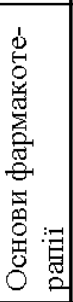 & 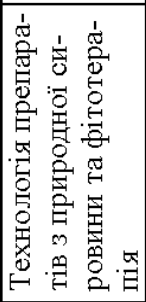 & 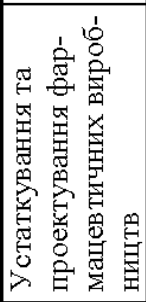 & 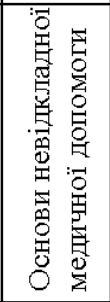 \\
\hline
\end{tabular}




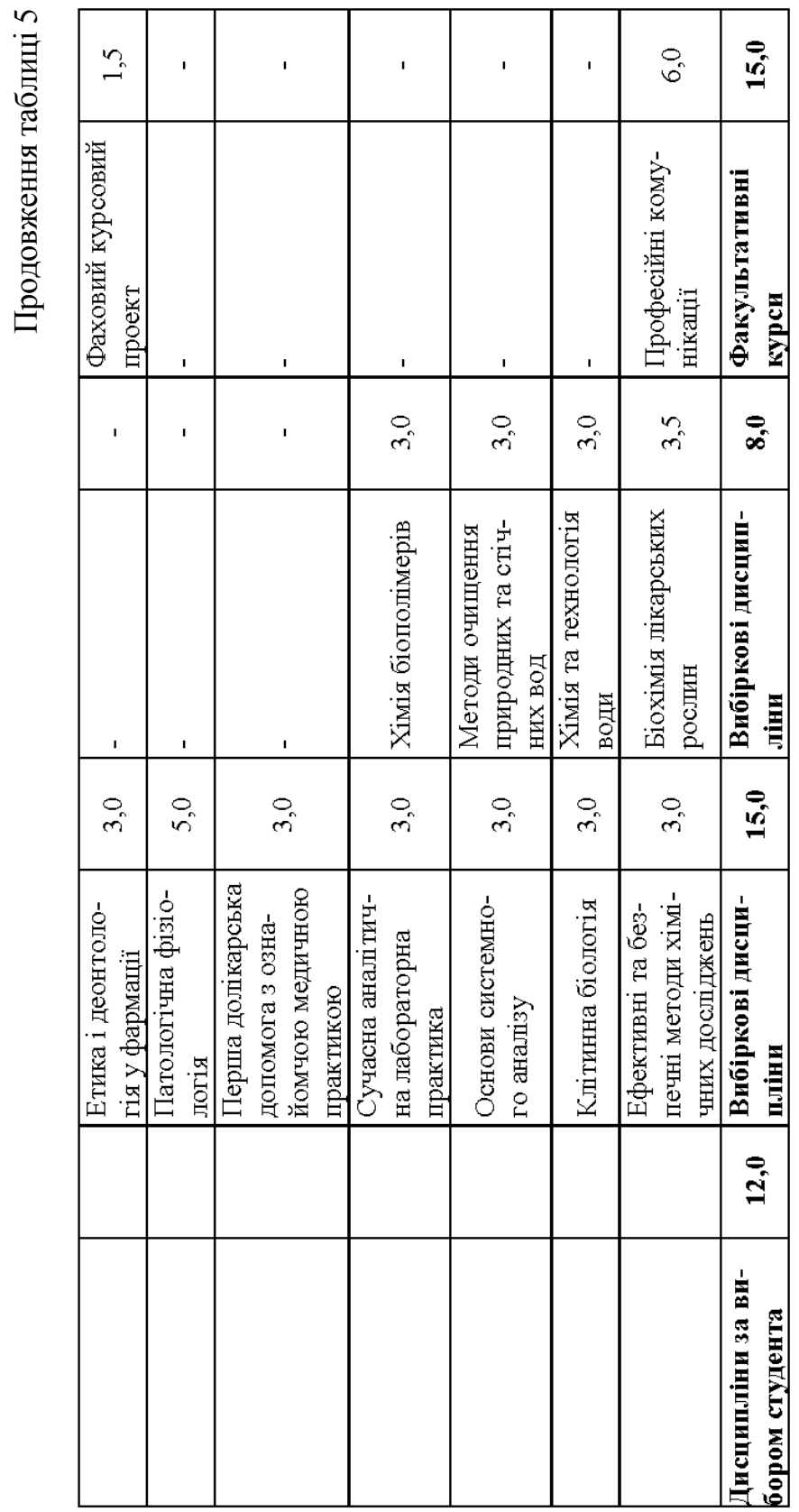


Порівнюючи обсяг підготовки бакалаврів трьох українських технічних ЗВО, слід зазначити, що велика увага приділяється у всіх закладах фундаментальній підготовці 3 таких дисциплін, як: вища математика, фізика, хімія (загальна, неорганічна, органічна, аналітична, фізична та колоїдна), філософія, іноземна та українська мови за професійним спрямуванням. Присутні дисципліни інженерного та інформаційного спрямування: інженерна та комп'ютерна графіка, інформатика, які є важливими для виконання фахового курсового проекту, а надалі - для виконання бакалаврської кваліфікаційної роботи. Обсяги вищезгаданих дисциплін (у кредитах СКТС) рівнозначні. У всіх цих ЗВО наявні такі види практик, як навчальна, технологічна (або виробнича) i практика за темою бакалаврської кваліфікаційної роботи. Атестація випускника здійснюється у формі публічного захисту (де монстраціï) кваліфікаційної роботи. Кожна 3 проаналізованих освітньопрофесійних програм $є$ унікальною, бо має свої особливості, певний набір компонентів (дисциплін), які слугують фаховій підготовці. Однак кожна 3 цих освітньо-професійних програм водночас універсальна в тому, що містить необхідний набір компетентностей, як загальних, так і фахових, які дозволять бакалаврам пристосовуватися до швидких змін і нових потреб на ринку праці, бути освіченими щодо інформації, вміти іiі аналізувати, активно діяти, швидко приймати рішення й навчатися впродовж усього життя.

\section{2. Аналіз освітньо-професійних програм (ОПП) першого (бакалаврського) рівня вищої освіти спеціальності 226 «Фармація, промислова фармація» із закордонними 3 ВО}

Порівняльний аналіз освітньо-професійних програм (далі ОПП) першого (бакалаврського) рівня вищої освіти спеціаль ності 226 «Фармація, промислова фармація» із закордонними університетами проводився 3 метою порівняння та виявлення спільних та відмінних характеристик щодо обсягу навчального навантаження здобувача вищої освіти за групами компонентів та циклами підготовки ОПП НУ «Львівської політехніки» та закордонних університетів (Університет Південної Кароліни 


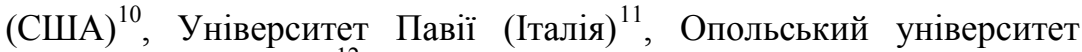
$\left(\right.$ Республіка Польща) ${ }^{12} .3$ метою проведення аналізу нами було взято інформацію лише з офіційних сайтів закладів вищої освіти.

Проведений нами аналіз дозволяє оцінити кредитну мобільність дисциплін ОПП першого (бакалаврського) рівня вищої освіти спеціальності 226 «Фармація, промислова фармація» НУ «Львівська політехніка».

За кордоном передбачено на майже всі спеціальності за відповідними галузями знань трирівневу освіту: бакалаврський перший рівень, магістерський другий рівень та третій рівень доктор філософії. Однак галузь знань «Охорона здоров'я», в яку входить спеціальність «Фармація, промислова фармація», майже у всіх країнах світу має два освітні рівні: магістерський та доктор філософії. Виключення становлять три країни у світі. Саме тому нами для порівняння ОПП на першому навчальному рівні було вибрано ЗВО цих країн: Університет Південної Кароліни (США), Університет Павії (Італія). Також нами було проведено порівняння нашої ОПП з ОПП Університету м. Ополє (Республіка Польща). Слід зауважити, що нами було взято лише чотири роки з ОПП, позаяк робочою програмою за цією спеціальністю також не передбачено бакалаврського навчального рівня.

ОПП НУ «Львівська політехніка» та проаналізованих ОПП закордонних університетів узгоджуються за поділом навчальних дисциплін на обов'язкові навчальні дисципліни, фахові навчальні дисципліни та вибіркові дисципліни та їхнім обсягом.

Особливістю ОПП НУ «Львівська політехніка» є вивчення таких дисциплін, як «Історія державності», «Українська мова (за професійним спрямуванням)», «Основи лабораторної функціональної діагностики», «Устаткування та проектування фармацевтичних виробництв», та більше уваги приділяється різним видам практики.

${ }^{10}$ Навчальна програма Університету Південної Кароліни. URL: https://sc.edu/study/ colleges_schools/pharmacy/pharmacy_education/pharmaceutical_sciences/bachelors/core_ curriculum/index.php.

${ }^{11}$ Навчальна програма Університету Павії. URL: http://www-4.unipv.it/ offertaformativa/portale/curriculum.php?lingua $=1 \&$ annoCorrente $=2020 / 2021 \&$ SelectedC $\mathrm{dsId}=146 \&$ codicePercorso $=00$ \&label $=$ PERCORSO $\% 20$ COMUNE $\&$ corso $=$ CHIMICA $\%$ 20E\%20TECNOLOGIA\%20FARMACEUTICHE.

${ }^{12}$ Навчальна програма Опольського Університету. URL: http://wch.uni.opole.pl/ programy-studiow. 
В Університеті Південної Кароліни (США) не виділяються кредити на вивчення іноземної мови, оскільки все навчання проводиться англійською мовою, і обов'язковою вимогою для вступу є володіння цією мовою.

Слід зазначити, що ОПП Університету Павії (Італія) не містить дисципліни «Філософія», проте виділяється 3 кредити ECTS на вивчення предмету «Доставка та направлення ліків», який схожий за змістом на курс «Фармакокінетика», що вивчається на першому (бакалаврському) рівні вищої освіти спеціальності 226 «Фармація, промислова фармація» НУ «Львівська політехніка».

В Опольскому університет (Республіка Польща) не виділяються кредити на вивчення таких дисциплін, як «Фізика» та «Фізична хімія». Особливістю ОПП цього університету $є$ наявність дисципліни «Фармацевтична біотехнологія», на вивчення якої виділяється 2 кредити.

Оскільки НУ «Львівська політехніка» готує спеціалістів у тому числі для фармацевтичної промисловості, важливими компонентами ОПП є такі дисципліни інженерного спрямування: «Процеси та апарати фармацевтичних виробництв» (8 кредитів), «Устаткування та проектування фармацевтичних виробництв» (8 кредитів), що становить $18 \%$ від кількості кредитів, виділених для циклу професійної підготовки, або $9 \%$ від обов'язкових компонентів спеціальності. Завершення бакалаврської програми НУ «Львівська політехніка» передбачає обов'язкове виконання i бакалаврської кваліфікаційної роботи, що не $є$ характерним для закордонних закладів вищої освіти, ОПП яких аналізувались (порівнювались).

Вміст фахових дисциплін у загальному обсязі підготовки бакалавра:

- НУ «Львівська політехніка» становить 80\%;

- Університет Південної Кароліни (США) -85\%;

- Університет Павії (Італія) - 90\%;

- Опольський університет (Республіка Польща)- 90\%.

Вважаємо, що для вдосконалення рівня фахової підготовки бакалаврів за спеціальністю 226 «Фармація, промислова фармація» доцільно підвищити відсоток дисциплін професійного спрямування на 10\%, що наблизить відповідну ОПП НУ «Львівська політехніка» до світових стандартів. 


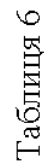

\begin{tabular}{|c|c|c|c|c|c|c|c|c|c|}
\hline \multirow{2}{*}{ 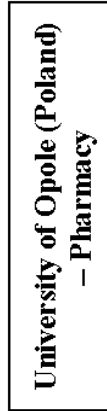 } & 量量 & $0_{n}$ & & 1 & $\stackrel{0}{-}$ & ${ }_{m}^{\circ}$ & in & $\begin{array}{l}\text { I } \\
\text { I }\end{array}$ & 0 \\
\hline & 氡 & 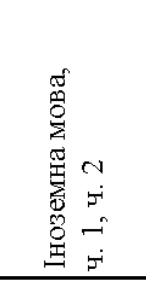 & & 1 & 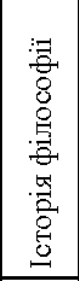 & 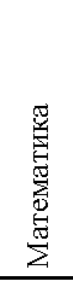 & 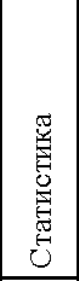 & 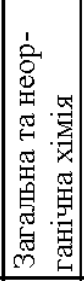 & 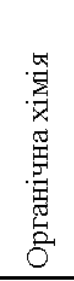 \\
\hline \multirow{2}{*}{ 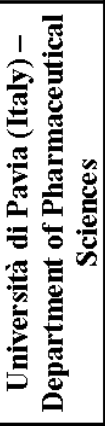 } & 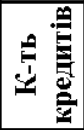 & $\mathrm{O}_{\mathrm{n}}$ & 1 & 1 & 1 & $\stackrel{\circ}{6}$ & & $0_{n}$ & $\begin{array}{l}\circ \\
\text { n }\end{array}$ \\
\hline & 昰 & 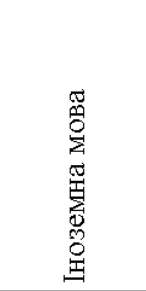 & 1 & 1 & I & 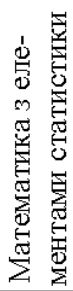 & & 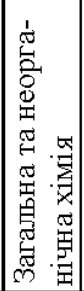 & 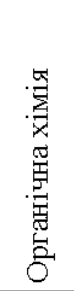 \\
\hline \multirow{2}{*}{ 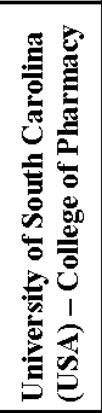 } & 鱼 & 1 & 1 & 1 & $\stackrel{\circ}{n}_{m}$ & $\stackrel{O}{n}^{\prime}$ & $\stackrel{\circ}{m}$ & $\stackrel{\circ}{\infty}$ & $\stackrel{\circ}{\circ}$ \\
\hline & 产 & 1 & 1 & 1 & 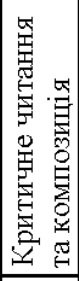 & 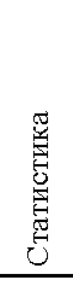 & 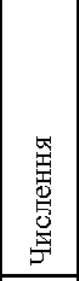 & 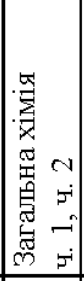 & 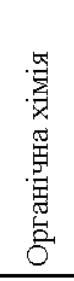 \\
\hline \multirow{2}{*}{ 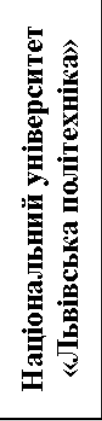 } & 曽 & $\begin{array}{l}\stackrel{0}{n} \\
\text {. }\end{array}$ & m. & $\mathrm{O}_{\mathrm{m}}$ & $\overbrace{m}$ & $\overbrace{0}^{\circ}$ & $\overbrace{0}^{\circ}$ & $\begin{array}{l}0 \\
n\end{array}$ & $\begin{array}{l}\circ \\
\Omega^{n}\end{array}$ \\
\hline & 氡 & 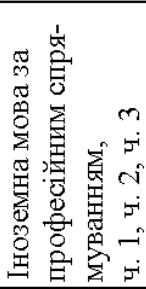 & 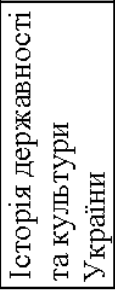 & 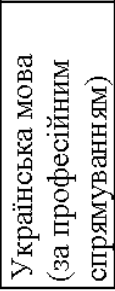 & 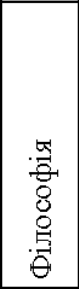 & 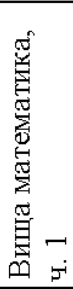 & 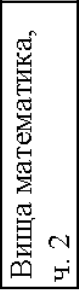 & 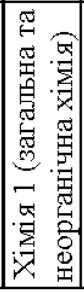 & 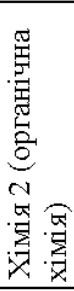 \\
\hline
\end{tabular}




\begin{tabular}{|c|c|c|c|c|c|c|c|c|}
\hline 1 & 1 & $\begin{array}{ccc}0 & 0 \\
\text { in } & n & 0\end{array}$ & $\stackrel{0}{6}$ & 1 & $\stackrel{0}{6}$ & $\stackrel{0}{n}$ & $\begin{array}{l}0 \\
0 \\
0\end{array}$ & iv \\
\hline 1 & 1 & 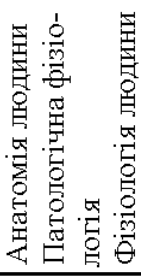 & 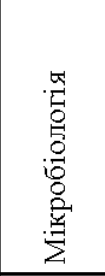 & 1 & 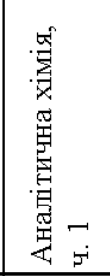 & 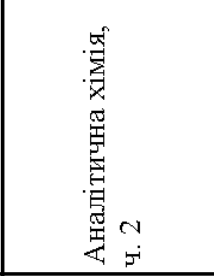 & 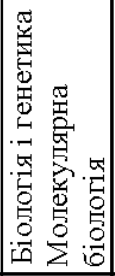 & 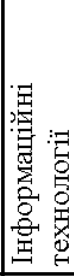 \\
\hline m & $\begin{array}{l}0 \\
6\end{array}$ & $\begin{array}{lll}0 & 0 \\
6 & 0 \\
0 & \text { N }\end{array}$ & $\overbrace{0}$ & $\begin{array}{l}0 \\
6\end{array}$ & $\begin{array}{r}0 \\
6\end{array}$ & $\stackrel{0}{0}$ & $\begin{array}{ll}0 & 0 \\
0 & 0\end{array}$ & $\begin{array}{l}0 \\
0\end{array}$ \\
\hline 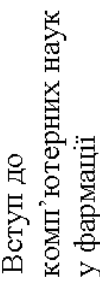 & 坣 & 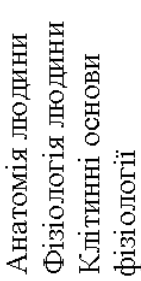 & 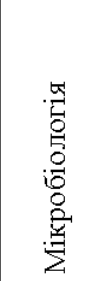 & 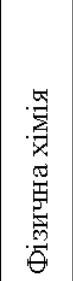 & 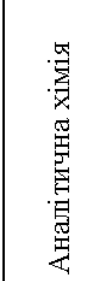 & 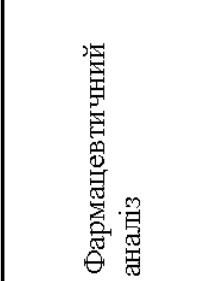 & 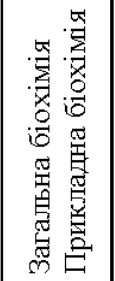 & 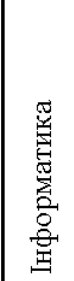 \\
\hline 1 & $\stackrel{0}{m}$ & $\stackrel{\circ}{m}$ & $\stackrel{0}{0} \stackrel{0}{\sim}$ & 1 & 1 & 1 & $0_{\infty}^{\infty}$ & 1 \\
\hline 1 & 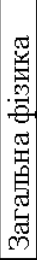 & 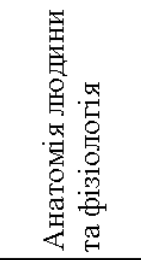 & 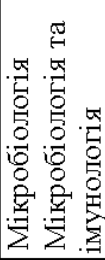 & 1 & 1 & I & 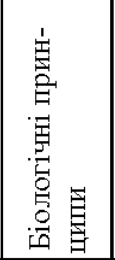 & I \\
\hline$\stackrel{\circ}{\forall}$ & 0 & $\stackrel{0}{n}$ & 0 & 0 & $\stackrel{\circ}{\nabla}$ & $\stackrel{\ominus}{\ominus} \stackrel{\ominus}{\forall}$ & $\stackrel{\circ}{\infty}$ & m. \\
\hline 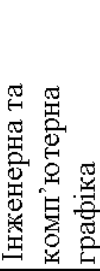 & 壱 & 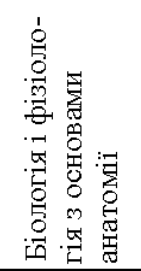 & 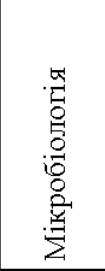 & 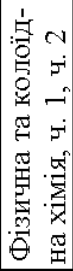 & 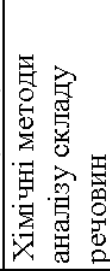 & 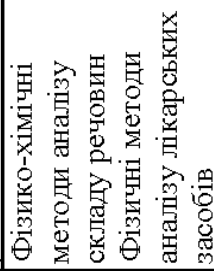 & 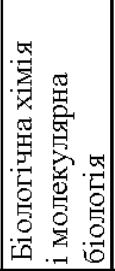 & 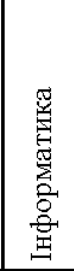 \\
\hline
\end{tabular}




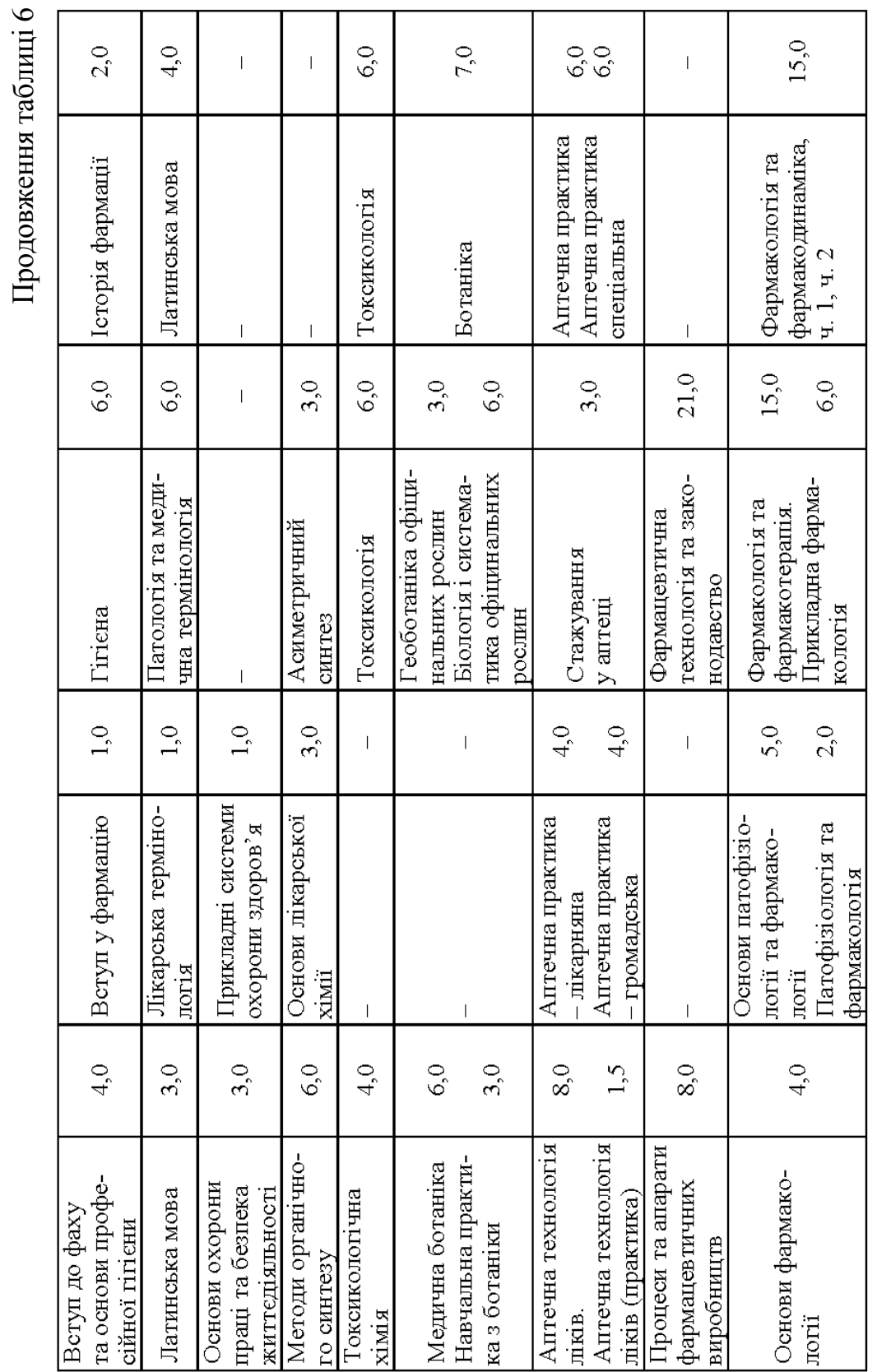




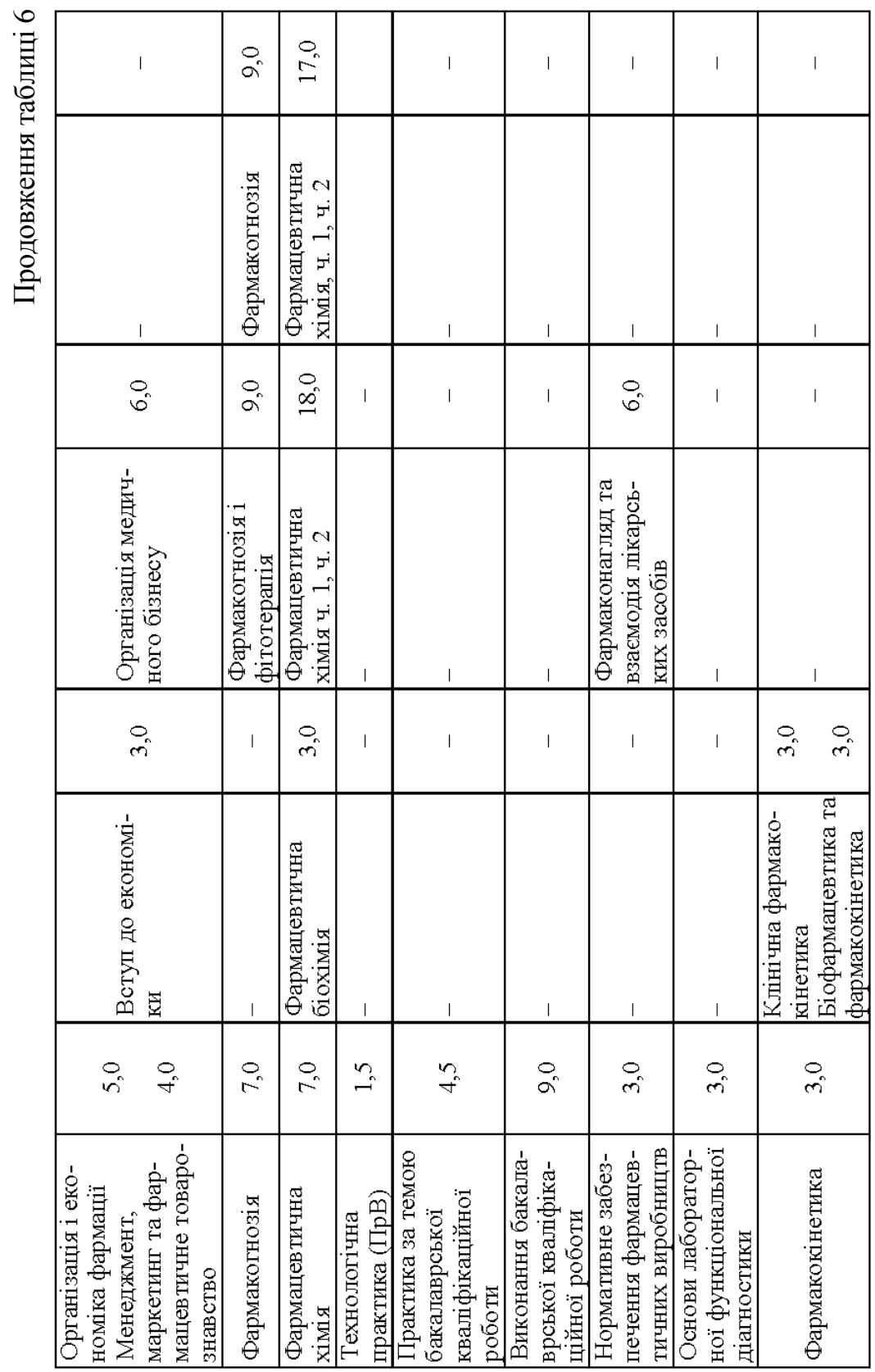


○

\begin{tabular}{|c|c|c|c|c|c|c|c|c|}
\hline$\stackrel{0}{6}$ & 1 & $\stackrel{0}{m}$ & $\stackrel{0}{0}$ & 1 & $\begin{array}{l}0 \\
\text { ㅇ }\end{array}$ & $\stackrel{0}{\sim}$ & $\begin{array}{l}0 \\
\stackrel{\Omega}{二}\end{array}$ & $\stackrel{\circ}{0}$ \\
\hline 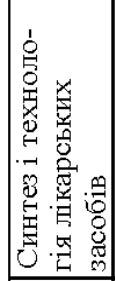 & 1 & 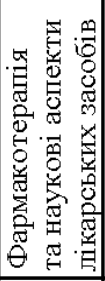 & 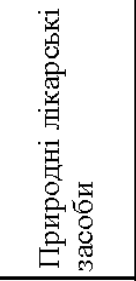 & 1 & 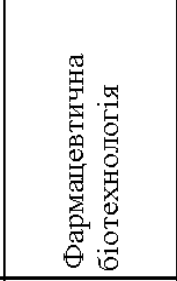 & 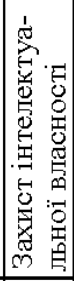 & 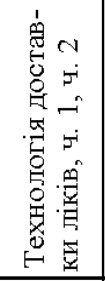 & 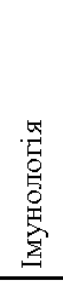 \\
\hline$\stackrel{\circ}{\circ}$ & 1 & $\stackrel{0}{6}$ & 1 & 1 & 1 & 1 & $\stackrel{\circ}{\mathrm{m}^{\prime}}$ & 1 \\
\hline 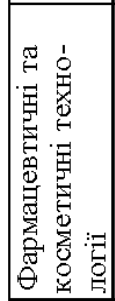 & 1 & 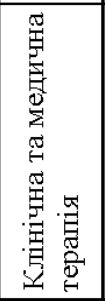 & 1 & 1 & 1 & 1 & 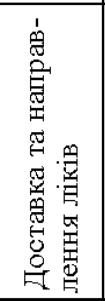 & 1 \\
\hline 1 & $\stackrel{0}{\forall}$ & $\begin{array}{l}0 \\
\text { in }\end{array}$ & 1 & 1 & $\stackrel{\circ}{\circ} \stackrel{0}{\sim}$ & $\stackrel{0}{n}^{n}$ & & $\stackrel{\circ}{m}$ \\
\hline I & 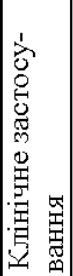 & 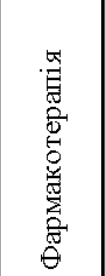 & 1 & 1 & 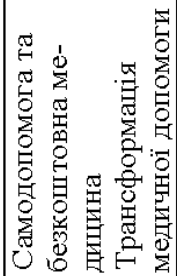 & 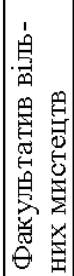 & 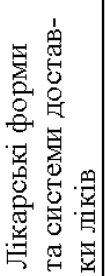 & 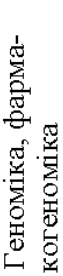 \\
\hline 0 & $\stackrel{\circ}{\forall}$ & 0 & $\begin{array}{l}0 \\
n\end{array}$ & $\wp_{\infty}$ & $n$ & & & \\
\hline 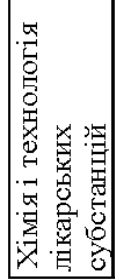 & 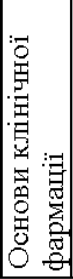 & 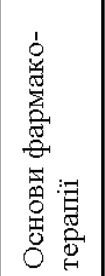 & 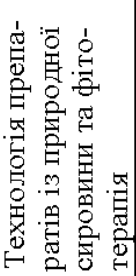 & 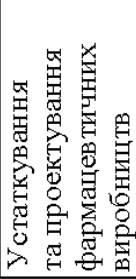 & 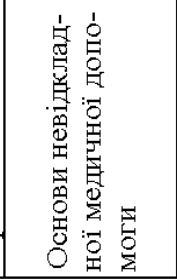 & & & \\
\hline
\end{tabular}




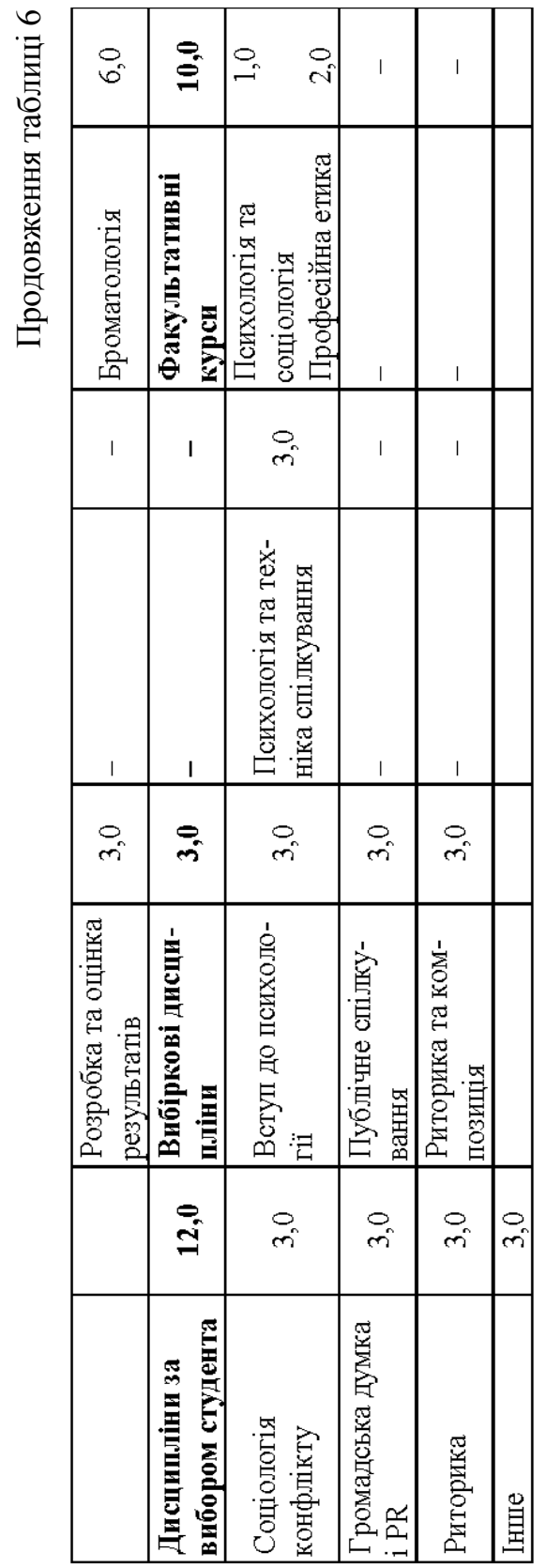




\section{ВИСНОВКИ}

Економіка XXI сторіччя диктує нові вимоги до випускників закладів вищої освіти, а саме не лише виконання певного завдання, а й уміння вирішувати проблеми, швидко орієнтуватися в сучасних умовах. Відповідно, виникає необхідність оновлювати освітні програми, вводити в них компоненти, які розвивають інтелектуальні здібності, ініціативність, пристосованість і впевненість для виконання роботи, тому адекватна модель фахівця $є$ компетентнісною, а не кваліфікаційною. Поняття «компетентність» знаходиться нині в епіцентрі світової думки, тому що воно розкриває якісно нові перспективи розуміння місії школи, життєвих результатів освітньої діяльності.

Упровадження компетентнісного підходу потребує модернізації фармацевтичної освіти, яка повинна полягати у формуванні нового освітнього середовища, зокрема, щодо запровадження в навчальний процес інформаційних, комунікаційних та аудіовізуальних технологій, полегшення доступу студентів i викладачів до структурованих навчально-методичних матеріалів, навчальних мультимедійних комплексів вищих навчальних закладів, забезпечення можливості зв'язку студента 3 викладачем, отримання консультації в онлайновому або офлайновому режимах.

Аналіз освітньо-професійних програм для підготовки бакалаврів 3 фармації, промислової фармації українських технічних ЗВО свідчить про їх спорідненість, навіть незважаючи на той факт, що натепер не існує затвердженого стандарту, отже, ця робота $\epsilon$ актуальною і важливою в умовах швидкого росту та розвитку фармацевтичного ринку.

Порівняння вітчизняних освітньо-професійних програм із зарубіжними освітньо-професійними програмами призвело до думки про необхідність збільшення обсягу професійних дисциплін за рахунок зменшення дисциплін загальної підготовки, оскільки це наблизить нас до світових стандартів i, без сумніву, сприятиме активнішій академічній мобільності студентів, підвищенню їхньої конкурентоспроможності на ринку праці.

\section{АНОТАЦІЯ}

3 огляду на приєднання України до Болонського процесу інтеграція в європейські простори вищої освіти і досліджень, прийняття прогресивного Закону України «Про вищу освіту» покликані змінити національну вищу освіту i, звісно, іiі ключові складники і чинники - освітні програми і відповідні кваліфікації 
(ступені), зазначити проблематику та результати дослідження. У статті аналізується та порівнюється навчальний план підготовки здобувачів вищої освіти першого (бакалаврського) рівня спеціальності «Фармація, промислова фармація» вітчизняних та іноземних закладів вищої освіти. На основі проведеного аналізу визначено дисципліни, які відносяться до циклів загальної, професійної підготовки, а також циклу вибіркових дисциплін, їх відсотковий вміст та доцільність його корекції. Виявлено, що ОПП Національного університету «Львівська політехніка» першого (бакалаврського) рівня вищої освіти спеціальності «Фармація, промислова фармація» відповідає сучасним критеріям якості вищої освіти та дозволяє сформувати фахівця високого рівня.

\section{ЛІТЕРАТУРА}

1. Громовик Б.П., Горілик А.В. Неперервна фармацевтична освіта в Україні: науково-методичні аспекти управлінсько-економічної підготовки : монографія. Львів : Растр, 2012. № 7. 166 с. С. 51.

2. Mertens D., Hopson R. Advancing evaluation of STEM efforts through attention to diversity and culture. Critical Issues in STEM Evaluation. 2006. № 109. P. 42. URL: https://doi.org/10.1002/ev.177.

3. Тараненко I. Розвиток життєвої компетентності та соціальної інтеграції: досвід Європейських країн ; за ред. І.Г. Єрмакова Кроки до компетентності та інтеграциї в суспільстві. Київ : «Контекст», 2000. 129 с.

4. Кубенко I.M. Що таке компетентність і як іï розуміють в освіті. Додаток до електронного журналу «Теорія та методика управління освітою». 2010. Вип № 1. С. 12.

5. З'їди фармації України - історія розвитку галузі / В.П. Черних та ін. Вісник фармащії. 2012. № 1 (69). С. 3-5. 7 с.

6. Розроблення освітніх програм. Методичні рекомендації / В.М. Захарченко та ін. ; за ред. В.Г. Кременя. Київ : Пріоритети, 2014. 120 с. C. 43.

7. Освітньо-професійна програма Київського міжнародного університету. URL: https://kymu.edu.ua/osvitnya-programa-farmatsiya.

8. Освітньо-професійна програма Одеського національного політехнічного університету. URL: https://opu.ua/education/programs/ bac-226-1.

9. Освітньо-професійна програма Київського національного університету технологій та дизайну. URL: https://knutd.edu.ua/ekts/ opfchbt/opfchbt-bhf/disc-bchf. 
10.Навчальна програма Університету Південної Кароліни. URL:https://sc.edu/study/colleges_schools/pharmacy/pharmacy_educatio n/pharmaceutical_sciences/bachelors/core_curriculum/index.php.

11.Навчальна програма Університету Павії. URL: http://www-4.unipv.it/offertaformativa/portale/curriculum.php?lingua= $1 \&$ annoCorrente $=2020 / 2021 \&$ SelectedCdsId $=146 \&$ codicePercorso $=00 \&$ label $=$ PERCORSO $\% 20 \mathrm{COMUNE} \&$ corso $=\mathrm{CHIMICA} \% 20 \mathrm{E} \% 20 \mathrm{TECNO}$ LOGIA\%20FARMACEUTICHE.

12.Навчальна програма Опольського Університету. URL: http://wch.uni.opole.pl/programy-studiow.

\section{Information about the authors:} Krvavych A. S., Candidate of Technical Sciences, Senior Lecturer at the Department of Technology of Biologically Active Substances, Pharmacy and Biotechnology Lviv Polytechnic National University 12, Stepana Bandery str., Lviv, 79000, Ukraine

Hubytska I. I., Candidate of Chemical Sciences, Associate Professor at the Department of Technology of Biologically Active Substances, Pharmacy and Biotechnology Lviv Polytechnic National University 12, Stepana Bandery str., Lviv, 79000, Ukraine 